\title{
บusisersaly
}

\section{How heat pumps and thermal energy storage can be used to manage wind power: A study of Ireland}

Inna, V., Keatley, P., Shah, N., Green, R., \& Hewitt, N. (2018). How heat pumps and thermal energy storage can be used to manage wind power: A study of Ireland. Energy, 157, 539-549.

https://doi.org/10.1016/j.energy.2018.03.001

Link to publication record in Ulster University Research Portal

Published in:

Energy

Publication Status:

Published (in print/issue): 15/08/2018

DOI:

10.1016/j.energy.2018.03.001

\section{Document Version}

Author Accepted version

\section{General rights}

Copyright for the publications made accessible via Ulster University's Research Portal is retained by the author(s) and / or other copyright owners and it is a condition of accessing these publications that users recognise and abide by the legal requirements associated with these rights.

\section{Take down policy}

The Research Portal is Ulster University's institutional repository that provides access to Ulster's research outputs. Every effort has been made to ensure that content in the Research Portal does not infringe any person's rights, or applicable UK laws. If you discover content in the Research Portal that you believe breaches copyright or violates any law, please contact pure-support@ulster.ac.uk. 


\section{How heat pumps and thermal energy storage can be used to manage wind power: a study of Ireland.}

Abstract

Although energy for heating and cooling represents the largest proportion of demand, little progress towards meeting environmental targets has been achieved in these sectors. The recent rapid progress in integrating renewable energy into the electricity sector however, can help in decarbonising heat by electrification. This paper investigates the impacts and benefits of heat electrification in a wind dominated market by considering two options; with heat pumps, and with direct electric heating, both operated with energy storage. The Irish all-island electricity market is used as a case study. Modelling results reveal the significant potential of heat pump electrification, delivering at least two and three times less carbon emissions respectively, when compared with conventional options such as gas or oil for $20 \%$ of domestic sector of the All Ireland market. Heat electrification using direct, resistive heating systems is found to be the most carbon intensive method. Energy storage systems combined with heat pumps could deliver potentially significant benefits in terms of emissions reductions, efficient market operation and mitigating the impacts of variable renewable energy on baseload generation. The main barrier to heat electrification in the all island market is the absence of appropriate policy measures to support relevant technologies.

Key words: heat electrification, heat pumps, direct resistive heating, thermal storage, electricity market model

\section{Introduction}

In order to decarbonise the energy system, strict measures have to be applied in its three sectors: heating and cooling, transport and electricity. Most progress to date has been achieved in electricity. Heating and cooling however, is the largest area of energy demand, consuming around 50\% of final energy supply in the EU, with fossil fuels accounting for 75\% (EU COMMISSION, 2016). In its heating and cooling strategy, therefore, the EU Commission has emphasised the requirement to increase the utilisation of renewable energy for heating and cooling, and to move towards smart, efficient and sustainable heating and cooling systems (ibid.).

The Northern Ireland (NI) and Republic of Ireland (RoI) domestic sectors are currently heavily dependent on oil heating, which supplies 62.8\% (NISRA, 2015) and 43.8\% (SEAI, 2013) of households in the two jurisdictions respectively. Despite the targets to achieve $12 \%$ of final heating demand from renewable sources in the Republic of Ireland (DCENR, 2009) and 10\% (DETINI, 2010) in Northern Ireland by 2020, slow progress so far suggests that these targets are unlikely to be met. Given the absence of significant biofuel potential and limited gas networks in Ireland, combined with one of the best wind and tidal resources in the world, electrification could be a winning solution for the heating sectors in both jurisdictions (A. Chiodi, 2013). 
Electrification can be achieved with either traditional direct electrical heating (DEH), or electrification with heat pumps (HP). DEH converts electrical energy into heat by means of electrical resistance, and can be realised with radiant, convection, fan or storage heaters. At the moment, approximately 8.5\% of households in the RoI (SEAI, 2013) and $3.5 \%$ of households in NI (NISRA, 2015) are using electric, predominantly resistive storage, heating.

Heat pumps absorb low-temperature thermal energy from the environment, then use electrically driven compressors to 'pump' it to higher temperatures using the refrigeration cycle. The major benefit of heat pumps is their efficiency, defined as their Coefficient of Performance (CoP) which ranges from 2 to 4.5. The CoP for DEH can never be higher than 1 . The main difference between heat pumps is the source of their thermal energy, which can be the air, surface water or the ground. While each type has its own advantages and disadvantages, air source heat pumps (ASHP) are currently the cheapest and most suitable solution for typical housing retrofits (Kelly \& Cockroft, 2011), (V. Bianco, 2017). Furthermore, the vast majority of homes are heated with hydronic radiators and therefore an air-to-water heat pump is a viable solution. This is highly compatible therefore with water based thermal storage and contributes the ease of installation.

Traditionally, electric heating using low-efficiency DEH has been considered the most expensive and carbon intensive type of heating, as it has used electricity produced from fossil fuel-fired power stations, which incur substantial losses during production, transmission, distribution and utilisation. The increased share of renewables in the generation mix however could potentially change this situation by using carbon-free fuel for heating purpose through electrification of the heating sector.

As wind energy is variable, generation may not coincide in time with heat demand, requiring energy storage to maximise the benefits of electrification. Electricity is currently more expensive to store than heat energy is. Electric heating, combined with heat storage, can supply low-carbon heat during peak hours or during periods of excessive wind energy, at the same type reducing wind curtailments, and helping in managing the operation of the electricity market.

This paper aims to investigate the potential of heat electrification using the Irish allisland Single Electricity Market (SEM), with a high proportion of variable renewable energy, as a case study. The analysis is performed by using a cost-optimisation market simulation model to compare the costs and benefits of DEH and HP, both coupled with thermal storage.

The Single Electricity Market has been chosen for a number of reasons: it is relatively small, with limited connection to the European Energy Market and with very ambitious renewable, mostly wind energy targets. This means that it will experience (and is already experiencing) the challenges of a high share of variable renewable generation before most other countries 
(F. Gaffney, 2017), (E.Denny, 2010). As other countries decarbonise, however, they may experience similar issues: Great Britain is also predicted to have high levels of wind generation in the 2030s. It is possible that analogous problems may arise in systems with high levels of solar PV and an air conditioning load, although the particular technologies and patterns involved are of course very different.

The paper is structured as follows;

- heating demand in the domestic sector is analysed and appropriate scenarios for its future decarbonisation are created based on policy goals and industry readiness;

- a modelling methodology is developed in order to investigate the impact and relative advantages of different types of heat electrification on the electricity market;

- the major modelling results are discussed;

- the economic potential for heat electrification and the government support needed in order to realise the scenarios considered in this paper are examined.

\section{Heat electrification potential in the SEM}

Electrification of the heating sector will create additional demand for electricity. Heating demand varies by season and time of day. While current electricity demand shows less significant seasonal variations, the daily pattern during the heating season is still correlated with heat demand. Demand for cooling in the domestic sector in Ireland is negligible.

The main challenge to electrification of the heating sector is to manage the system during peak times. During off-peak hours baseload generators provide relatively cheap electricity to the market; during peak periods high-cost, low-efficiency peaking generators have to be synchronised with the system. As domestic heating demand is highly correlated with electricity demand, electrified heat could potentially increase peaks in electricity demand compared with the current situation. Figure 2.1 shows the interrelationship between domestic electricity and gas consumption, as well as wholesale market electricity demand for a typical winter day (CER, 2014), (CER, NIAUR, 2012).

Energy storage technologies could however help to manage increases in peak electricity demand which arise from heat electrification. Strbac et al (2010) concluded that a projected increase of $92 \%$ in peak demand due to heat electrification can be reduced by two-thirds if thermal energy storage and electric vehicle optimised technology control are applied. 
There are many types of energy storage solutions available for the domestic sector, including several which are still at the research and development stage (H. Zhao, 2015), (Xi. Luo, 2015) (G.Strbac, 2012). From the large range of domestic storage technologies which are already available, sensible thermal energy storage is one of the most developed (Eames, 2014). The application of thermal energy storage solutions to facilitate the electrification of the heating sector is considered for this study.

Different strategies for heat pumps and energy storage control range from customerled, to automatic control in response to market conditions (D. Fischera, 2017). Customer control often leads to sub-optimal operation, resulting from socio-economic factors which are beyond the scope of this study. For example, a Carbon Trust study with heat pumps and time of use electricity tariffs in residential areas showed that people often switched on heating during peak periods, ignoring price incentives (Energy Saving Trust, 2013).

Peak heating demand could potentially coincide with peak electricity demand and thereby non-optimal customer led storage control instead of reducing the overall peak in demand can either increase it or simply create another peak, causing the same challenge for market operation (Baringa, 2012).

Moreover, the increasing share of time-variable renewable generators can increase the unpredictability and magnitude of peaks in electricity prices, since these typically depend on demand net of renewable generation. This makes it difficult for customers to optimally control storage operation in order to benefit from market conditions.

Past experience with inefficient storage heating systems and associated tariffs (such as Economy $7^{1}$ ) led to thermal discomfort and high levels of customer dissatisfaction with storage heating systems (IPSOS MORI, 2012). Poor control systems led to difficulty for customers in striking a balance between thermal comfort and economy. New generation DEH storage systems (Dimplex, 2015) claim to be more efficient and easier to control, but still require detailed analysis in operation.

Taking these factors into account, the current study investigates one of the most efficient systems for heat electrification with integrated thermal storage currently available, which is controlled automatically in line with market conditions, and which does not compromise the thermal comfort of domestic users. Thermal storage is used to link heat demand with market operation and is optimised by an energy market model in accordance with power market requirements. This means that heat is delivered according to the existing customer requirements (i.e., no changes in heating demand profile are considered).

${ }^{1}$ This provided relatively cheap electricity for seven hours overnight, during which a storage heater would draw power, offset by relatively more expensive power during the daytime hours. 
Heat pumps are expected to play a significant role in the decarbonisation of the heating sector in the UK. National Grid forecasts the installation of between 0.6 and 5.7 million heat pumps by 2030 in GB (National Grid, 2014). This constitutes between circa 1.9\% $17.6 \%$ of all projected residential sector dwellings and would add between $1.5 \mathrm{TWh}$ and 13.5 TWh to annual electricity demand.

In a parallel report the Committee on Climate Change in the $4^{\text {th }}$ Carbon Budget estimated that up to 6.8 million heat pumps would be needed in the residential sector by 2030 under the "Medium Abatement" scenario. The critical path for meeting 2050 targets requires the uptake of at least 2.3 million heat pumps in the residential sector by 2030 , whilst the "High abatement" scenario assumes up to $8 \mathrm{~m}$ or $32 \%$ of the residential sector electrified with heat pumps (Committee on Climate Change, 2010), Table 3.5. Despite the fact that in the Carbon Budget Review potential uptake for heat pumps in the residential sector has been reduced from $25 \%$ to $13 \%$ of domestic stock (medium scenario) (Committee on Climate Change, 2013), heat pumps are still recognised as the most cost-efficient option for off-gas grid homes (Frontier Economics, ElementEnergy, 2013).

In Northern Ireland and the Republic of Ireland, limited gas networks and high dependence on oil in heating markets make heat pumps a more likely technology for heat decarbonisation. The Sustainable Energy Authority of Ireland (SEAI) suggests that the implementation of current national and EU Building Regulations, which include very basic standards for energy efficiency (minimum boiler efficiency of $85 \%$, phasing out of incandescent bulbs) could result in the housing sector in the Republic of Ireland reducing its output to circa 3 tonnes $\mathrm{CO2}$ per dwelling by 2050 from circa 7.5 tonnes CO2 per dwelling in 2010 (SEAI, 2011). On the other hand, SEAI research suggests that it is possible to achieve nearly $90 \%$ decarbonisation of the residential sector, if significant retrofit measures, deployment of renewables and low and zero carbon technologies, as well as high levels of electrification, are applied (SEAI, 2011). This requires the electrification of at least 1.5 million households by 2050 and initially at least 180,000 residential dwelling or $9 \%$ of the (SEAI, 2011).

The most significant barrier to heat electrification for the domestic sector is the limited capacity of the distribution network. However, because of their high CoP (typically 3 , compared with 1 for DEH), heat pumps have a significant advantage in that they can provide three times the amount of heat that DEH can provide, for the same network capacity. Assessments of the ability of low voltage networks to accommodate electrification (or other forms of demand side management) have not yet been performed at scale. However, several studies suggest that current network capacity in urban areas could allow between 20\% (Akmal M., 2011) and 30\% (P. Mancarella, C. K. Gan, G. Strbac, 2011) of existing fossil fuel heat demand to be displaced by heat pumps. 
These studies were performed for typical UK/Irish distribution networks and were approved by several network operators as being representative of networks overall (C.K. Gan, et al., 2011), (B.E. Peter Richardson, 2012).

Taking into account both policy goals and technical barriers therefore, a figure of $20 \%$ of domestic heat demand is assumed to be served by electrified heat for modelling purposes in this study. This figure reflects a technically achievable share of heat demand for heat pumps, given existing network capacity. $20 \%$ is probably unachievable using DEH in isolation, without making significant upgrades to the distribution network. It should therefore be borne in mind that electrification of heat through DEH alone would probably require additional grid investment.

Decarbonisation of the energy sector in general, and heat electrification in particular, will require policy support. The scenarios created assume this will be provided, alongside strong support for the deployment of renewable energy, so assume that wind provides $52 \%$ of total energy demand in the SEM.

The move to electric heating provides an opportunity to offset the variability in renewable generation via heat storage. There are many types of thermal energy storage: sensible thermal, phase-change materials and thermo-chemical energy storage $(\mathrm{H}$. Zhang, 2016). The most widely used technology for domestic applications is sensible heat (hot water technologies), whilst phase-change materials and thermo-chemical storage are still at the early stage of their development (Eames, 2014). Therefore, sensible heat (hot water) energy storage is assumed for this study to accompany HP or DEH.

Scenarios considering the impact of DEH and heat pumps without storage are investigated. In addition, thermal storage with the ability to supply 1, 2, 3 and 4 hours of domestic heat demand are used to create additional scenarios. An overview of these scenarios created is shown in table 3.1.

\section{Methodology}

The Single Electricity Market (SEM) model is used to investigate the impact of heat electrification on a day ahead, gross pool market. The model was developed using Plexos for Power Systems software and optimised with the FICO Express-MP solver. Plexos is a commercial tool used by the Commission for Energy Regulation to model the Single Electricity Market, and is also used in academic research projects (V. Bianco, 2015), (Deane JP, O'Gallachoir BP., 2012), (Nsanzineza R., 2017).

This section gives an overview of the SEM Plexos model, followed by the methodology for heat electrification and a description of its representation in the model. The latter consists of stages including analysis of future heat demand, heat electrification methodology and thermal storage modelling overview. 
As the aim of this study is to investigate the impact of different options for market electrification on the all-island electricity market, and as the Plexos model is not developed to work at individual household scale, the methodology represents the effect of domestic heat electrification on the wholesale market in accordance with the scenarios described.

\subsection{Electricity market model overview}

The market model is designed to reflect real market structure and operation, therefore it consists of two regions (the SEM and the GB regions) linked together with two interconnectors with $1 \mathrm{GW}$ of total capacity. The SEM region is modelled in detail. Thermal generators are presented at unit resolution and the model includes detailed techno-economic characteristics and constraints, such as: heat rate functions, start-up profiles, ramp rates, minimum up and down times, forced and maintenance outage profiles. Technical characteristics, combined with economic assumptions (fuel and carbon prices, variable operating and maintenance [VO\&M] costs) replicate the complex bids submitted by SEM generators on a daily basis. The GB market has a simplified structure but is included to simulate power flows from/to the SEM. It is assumed that there are no direct links from the SEM to continental Europe, as the current Project of Common Interest funded by the EU is devoted to studies regarding capacity and route (EirGrid, 2017).

Unit commitment and spot price settlement are optimised based on the unconstrained mandatory SEM gross pool market structure. They are defined by chronological market optimisation using a mixed integer algorithm, and total system costs minimisation as the objective function.

The generation portfolio of the SEM is represented by taking into account the current generation fleet, as well as potential changes in future generation proposed by the system operators (EirGrid, SONI, 2015). As current projections only include changes in the generation portfolio up to 2024, further changes are based on the average technical life of thermal generators and the assumed progress in decarbonisation. The latter considers the adoption of stricter environmental targets, higher levels of renewable generation deployment, decommissioning of older and carbon intensive generators (i.e. coal, oil) and the deployment of environmentally friendly technologies (i.e. CCS, etc.). Figure 4.1 shows the SEM generation installed capacities by fuel type. More details about the market model and its generation portfolio are given in (Vorushylo I., 2016).

As with the SEM generation portfolio, the GB market assumes further progress in renewable deployment and system decarbonisation. The market development scenario 
replicates the "Gone Green" scenario of National Grid's Future Energy Scenarios (National Grid, 2014). Macroeconomic assumptions (fuel and carbon costs, demand profile, etc.) for the 2030 models are presented in tables 4.1 and 4.2 below.

Electricity demand has been defined by quadratic extrapolation of the 2015 total electricity demand taking into account total demand and peak demand projections (SEM Committee, 2014) (EirGrid, SONI, 2017).

\subsection{Heat electrification methodology}

\subsubsection{Future heat demand}

The future domestic heat profile has been defined by linear extrapolation of the current profile taking into account projections for future housing stock changes. The current weighted average domestic heat demand is based on smart metering trials involving 9000 households in the ROI (CER, 2014) and 200 households in Northern Ireland (NI Electricity, 2014). The profiles obtained are considered statistically robust and a good representation of the average all-island domestic heating profile. The domestic heating profile in Ireland has seasonal characteristics (figure 3.3). The profiles obtained represent one-year domestic heat consumption at one-hour resolution.

It is expected that the all-island housing stock will comprise circa 2,936,030 houses in 2030 in both jurisdictions (NISRA, 2015), (SEAI, 2013). Multiplication of the normalised hourly heat profile by a factor of 563,704 (20\% of 2030 housing stock) creates the allisland future heating demand profile for electrification.

\subsubsection{Heat electrification}

The projected 2030 heat demand has been used to represent the load for direct (resistive) electrical heating, assuming a Coefficient of Performance (CoP) of 1. It was included directly into the electricity model as additional domestic electricity demand.

As mentioned earlier, the main advantage of heat pumps in comparison to DEH is their superior efficiency. In order to represent heat pump electrical load, the heat demand profile has been modified to take into account projections for the future CoP of heat pumps. Although historic heat pump field trials have shown significant differences between operation in laboratory and real houses (J.P. Green, S.A. Smith, and G. Strbac, 2002), it is assumed technological progress will lead to improvements in performance by 2030 . The laboratory performance efficiency of heat pumps has therefore been included in the modelling scenarios.

According to laboratory tests an air source heat pump (ASHP) achieves a CoP of between 2 and 3.5. Laboratory and field trial tests indicate that performance depends on weather conditions. An analysis performed on data from smart metering trials (CER, 
2014) (NI Electricity, 2014) shows 76\% inverse correlation between maximum ambient daily temperature and domestic heat consumption. This means that during cold winter days heat consumption increases and heat pumps operate less efficiently. Thermal storage performance is also influenced by weather conditions, as different amounts of energy are required to charge the thermal storage tank during cold winter nights compared to warm spring days for example.

In order to realistically represent heat pump performance, a dynamic function representing heat pump $\mathrm{CoP}$ has been defined based on laboratory test results (figure 4.3), (eq. 1)

$\mathrm{CoP}=0.0004 \times \mathrm{Temp}^{2}+0.046 \times \mathrm{Temp}+2.6782$

Where Temp - is an ambient temperature, measured in degrees Celsius.

Domestic heat consumption has been modified in accordance with this dynamic performance function in order to take ambient temperature into account. The additional electricity demand for HP and DEH is presented in table 4.3

\subsubsection{Thermal storage modelling}

Normalised winter demand represents the average domestic heat consumption. As every individual household has its own unique consumption pattern, the normalised profile represents a smoothed or average peak demand across the whole domestic sector. Analysis of individual household heat consumption shows an average peak demand of $9.96 \mathrm{~kW}$ (figure 4.4, table 4.4), whilst average demand is only $4.5 \mathrm{~kW}$. This factor is important for the sizing of energy storage tanks, as their parameters are based on individual household needs. This means that summative storage capacity across the domestic sector will significantly exceed the mean, and therefore can effectively contribute to the dealing with peak demand.

Average winter domestic peak demand per household (9.95kW, figure 4.4) multiplied by the number of households (circa 563, 704 households representing $20 \%$ of the future stock (NISRA, 2015), (SEAI, 2013)) and the assumed storage duration (1h, $2 \mathrm{~h}, 3 \mathrm{~h}$, $4 \mathrm{~h}$ ) has been used to define the total capacity of domestic thermal energy storage which is included in the model (table 4.5).

As mentioned earlier, automatic control of thermal storage operation has been assumed for all scenarios. This means that storage systems are assumed to be managed centrally to operate in line with wholesale market needs, without input from consumers.

The efficiency of hot water energy storage tanks varies in the range of $50 \%-90 \%$ at the moment (IEA-ETSAP, 2013), (Alva G., 2018). Assuming improvements in the future, we assume $80 \%$ efficiency of sensible energy storage in the 2030 market for all scenarios. 


\section{Modelling results}

The final set of modelling results considers scenarios for heat electrification using HP and DEH with and without thermal energy storage, and investigates their potential impact on the electricity market.

The higher efficiency of heat pumps creates significantly lower additional electricity demand than direct electric heating (figure 5.1).

While DEH can add up to $25 \%$ to peak demand in evening peak periods during winter, more efficient HP electrification adds less than $8 \%$ to deliver the same volume of heat.

Electrification with heat pumps adds between $2.80 \%$ (HP $+1 \mathrm{~h}$ ES) to $5 \%$ (HP only) of additional annual $\mathrm{CO} 2$ emissions to the electricity sector (table 5.1). The lower $\mathrm{CoP}$ for DEH logically has a more significant impact on the environment and adds between $13.72 \%$ (DEH +2h ES) to $16.58 \%$ (DEH only) of CO2 emissions per year.

The increased penetration of renewable generators in the 2030 generation fleet amplifies the beneficial impact of electrification on emissions (fig 5.2). As fossil fuel generation is displaced from the fuel mix, a given number of heat pumps will deliver increasing emissions reductions in parallel with increasing levels of grid renewables. In the scenarios described in this study, the capacity of heat pumps installed today would lead to a reduction of approximately $40 \%$ in $\mathrm{CO} 2$ emissions by 2030 (figure 5.2). Whilst DEH will generate more emissions than gas and oil heating in 2030 in the scenarios assumed, HP electrification results in less than half the $\mathrm{CO} 2$ emissions of gas, and approximately one third of the emissions of oil heating, clearly demonstrating the benefits of HP electrification in meeting environmental targets and decarbonising heating sector.

The benefits of thermal energy storage can also be observed from Figure 5.3, which shows one week of thermal storage operation and its influence on national demand.

As shown in Figure 5.3, by charging energy stores at off peak hours and discharging during peak hours, peaks in electricity demand are significantly reduced. This reduction relates directly to reduced carbon emissions and better system management, as it favours the operation of baseload units in preference to more expensive and carbon intensive peaking plants. Therefore, as shown in table 5.1, storage can help reduce $\mathrm{CO} 2$ emissions by circa $2 \%$ for HP scenarios and $3 \%$ for DEH scenarios.

In addition to this, energy storage systems can help in reducing wind curtailment. The major factor that influences wind curtailments in the real market dispatch is the level of system non-synchronous penetration (SNSP). The TSOs in Ireland aim to allow 75\% SNSP in the future system. Simulation of the proposed scenarios with application of the $75 \%$ SNSP limit suggests that under the BaU market development scenario, c. $7 \%$ of 
available wind energy will be curtailed. Demand side storage can significantly help in reducing wind curtailment and, despite additional electricity demand and an increase in peak demand, could reduce wind curtailment to $4.8 \%$ for HP scenarios and to $2.93 \%$ for DEH scenarios (Table 5.2).

In addition to better network management and reduced emissions, energy storage can also reduce the number of baseload generator starts. The simulation results show that without storage, the number of baseload generators start-ups increase by up to $16 \%$ for electrification with HP and by almost $40 \%$ for DEH. Energy storage systems significantly reduce the required starts by baseload generators, even in comparison with the $\mathrm{BaU}$ scenario, reducing it by up to $13 \%$ in the HP $+4 \mathrm{~h}$ storage scenario, and by $3 \%$ for DEH + 2 scenario.

It is worth noting that there is little difference between technical benefits (i.e. level of CO2 emissions, wind curtailments and the number of baseload starts, etc.) in the ES 1 and ES 4 models for both HP and DEH. This suggests that the energy market responds to the availability of any storage capacity rather than the total volume available. Storage that can shift one hour's worth of energy from peak to off-peak delivers similar benefits to four hours' storage. This is an especially important consideration for domestic energy storage, as stored energy volume corresponds directly to the size of domestic storage tanks, which is a limiting factor in typical Irish houses. On the other hand, the market model does not take into consideration network constraints, which will more likely require additional storage volume to manage especially distribution network limitations.

\section{Economic perspectives and policy prospects}

From an economic point of view, HP electrification requires circa $€ 360 \mathrm{M}$, or adds around $11 \%$ to the yearly total system costs, when compared with the BaU scenario. $\mathrm{DEH}$ is almost five times more expensive and requires an additional €1,713 $\mathrm{M}$ (or 52\%) per year, which makes it a very unattractive economic option. The addition of energy storage adds significant savings by reducing the total system cost of heat electrification by up to $5 \%$ for HP electrification and $30 \%$ for DEH (table 6.1).

Optimised management of heat electrification at 75\% SNSP can minimise the increase in total system dispatch costs to less than to $2.15 \%$ for the HP + 4 ES group of scenarios; and less than $5.6 \%$ for DEH + ES group of scenarios (Table 6.1). As total dispatch costs include total system costs and the costs associated with network constraints, they are a better indicator of what consumers are likely to pay.

The non-monetised benefits of storage, such as the 0\&M costs reduction associated with reduced baseload generator cycling and the management of distribution networks congestion, will bring considerable economic benefits to the SEM. The ability to provide aggregated ancillary services can further strengthen the case for electrification with HP 
and energy storage. Better wind power management will also allow wind farms to strengthen their position and receive a higher level of REFIT support.

Heat electrification, however, requires significant investments. At the moment total average costs for an ASHP (capital costs with installation) varies between $£ 6,000$ and $£ 10,000$ per house (Frontier Economics, ElementEnergy, 2013). If we assume a $10 \%$ reduction in the future capital costs of ASHP due to technology improvements, installations will still require between $€ 431$ and $€ 718 \mathrm{M} /$ year, or $€ 764$ - €1273 yearly per household to achieve $20 \%$ penetration of HP in the domestic heating sector (calculations are made assuming a social discount factor of 3.5\% and a 10-year economic life), (table 6.2). In order to motivate customers to install heat pumps appropriate supporting mechanisms need to be developed.

Thermal energy storage system costs vary considerably depending on the technology applied, operating temperature number of cycles. The cheapest form of thermal energy storage is sensible (hot water) storage. Its capital costs vary between $0.1-10 € / \mathrm{kW}$ (IEA, IRENA, ETSAP, 2013), requiring an investment of up to $€ 6.5 \mathrm{M}$ per annum.

Simulation results show that ES systems can save €14 - €16 M per annum for the HP group of scenarios (table 6.1), which means that the profits from price arbitrage are enough to cover the capital costs of sensible storage. However, limited space in a typical house in Ireland will potentially require other forms of storage to be considered. In order to install an energy storage system which can deliver $1 \mathrm{~h}$ of average household peak demand, a tank with the total volume of circa 870 litres is required. Community energy storage or phase-change materials could provide a solution. Phase-change materials or thermo-chemical technologies might offer energy storage solutions with considerably lower volume and space requirements and higher efficiency. However, capital costs are currently significant. Capital costs for PCM storage is in the region of 10 - $50 € / \mathrm{kWh}$, while capital costs for thermo-chemical storage ranges from 8 - 100 $€ / \mathrm{kWh}$ (IEA, IRENA, ETSAP, 2013), (Glatzmaier, 2011). Significant progress in technology development and cost reductions are therefore necessary.

It is difficult to compare the costs of HP electrification with alternatives such as gas heating. The capital cost of a new gas boiler ranges from $£ 500$ to $£ 2500$, with an additional $£ 500$ - $£ 1000$ required for installation, and around $£ 200$ per year for maintenance (DETINI, 2011). This is significantly lower than the capital cost of a heat pump. However, as mentioned, the gas network is relatively poorly developed on the island of Ireland. It is estimated that in total $£ 75 \mathrm{M}$ is needed to extend the network to the west and north-west of Northern Ireland, and between $£ 26$ and $£ 86 \mathrm{M}$ to connect a further 7,658 to 31,387 customers (DETINI, 2011). It is anticipated that extending the gas network to other regions will be even more expensive. Therefore if the total costs needed to extend the gas network to new customers (DETINI, 2010), (approximated to $20 \%$ share of households in the market) are compared with the costs required to install HPs, these are found to be similar in magnitude (table 6.2) with HP costs even lower than gas extension costs. 
This analysis, however, does not consider costs associated with the gas network maintenance. Also, the heat electrification scenarios proposed in this paper are based on the capacity available on the existing network. Upgrades and strengthening of the existing network to allow a higher share of electrified heat, or other types of electricity consumption such as electric vehicles, will require significant investment. However, if investments are required to either build new gas networks or to strengthen existing electricity infrastructure, it would seem obvious to favour the technology which can deliver lower carbon emissions from the outset.

The main barrier to decarbonisation of the heating sector in general, and heat pump integration in particular is the absence of appropriate policy instruments. The only supporting mechanism in the Republic of Ireland is recently launched Renewable Heat Scheme (Element Energy, Frontier Economics, 2017). Northern Ireland does not have any renewable heat incentive mechanisms at the moment which probably means an insignificant rate of technology uptake.

Energy storage systems have been significantly undervalued and only recently started to be recognised as a potential solution for the integration of variable renewables. Current government support is mainly focused on R\&D programme funding, which means that more serious government commitment is required to support the integration of energy storage and to stimulate private investors (Renewable Energy Association, 2016).

Moreover, despite the market reform taking place at the moment (EirGrid, 2016), incentives for demand side participants (especially at the domestic level) are missing. The potential benefits of thermal energy storage described in this paper are unlikely to be realised in the proposed market design. The only option for market participation is to make an agreement privately with retailers via some form of aggregation. Retailers, however, appear to be largely unenthusiastic about such contracts at the moment.

\section{Conclusions}

In conclusion, electrification of the heating sector with heat pumps in a wind dominated market could bring significant environmental benefits in comparison with alternative heating methods. Energy storage systems would help in mitigating the impact on peak electricity demand and thereby further reduce the emissions impact, while simultaneously optimising market operation and network management. The electrification of $20 \%$ of domestic heating demand would add only circa $3 \%$ to the total yearly electricity sector $\mathrm{CO} 2$ emissions, if combined with energy storage. Alternative gas or oil heating would result in at least two and three times more $\mathrm{CO} 2$ emissions respectively. 
Direct electric heating, however, shows greater environmental impact than gas or oil heating. In addition to this it will require significant market investments, which makes it economically not a viable option for heat decarbonisation.

Small-scale energy storage can bring significant benefits to the market in terms of reduction in peak consumer demand, improving the operating profile of baseload generators (even in comparison with the BaU scenario), reducing wind power curtailment and improving network management. However, the economic potential of thermal storage significantly depends on technology development. The current costs of thermal storage mean that only sensible storage installations have the potential to be economically efficient without additional support. The limited space available in many houses suggests a need for alternative ES technologies, such as phase-change materials or thermo-chemical technologies, which are currently expensive and require significant development.

HP electrification will require significant investment to cover the capital, installation and maintenance costs of HP deployment, plus an additional 2.2 - 5.2\% (depending on the level of energy storage) of total system dispatch costs for electricity market operation. However, if these costs are compared with the costs required to extend the gas network (which is poorly developed in Northern Ireland, for example), similar levels of investments are needed. Therefore if investments are needed in any case, it is obvious to favour lower carbon emissions technologies and give preference to HP technologies.

The scenarios described here are based on current network capabilities, however the uptake of a higher share of HP or other demand side technologies, such as electric vehicles or solar PV, will require additional investment in distribution networks.

The absence of appropriate policy support in both Northern Ireland and the Republic of Ireland are currently the major barriers to heat electrification. The benefits of demand side response are undervalued in the market. The only way for DSR to participate in the market and be at least partially rewarded for the services provided is through currently under-developed aggregated private contracts with retailers.

Acknowledgements

The authors gratefully acknowledge the support of the European Union INTERREG IVA SPIRE project (Grant number 036347) programme through the Special EU Projects Body (SEUPB). Further the authors wish to acknowledge the support of the Engineering and Physical Sciences Research Council (EPSRC) through the Interdisciplinary Centre for Storage, Transformation and Upgrading of Thermal Energy (i-STUTE) (Grant No. EP/K011847/1). We also express our gratitude to Energy Exemplar for the free academic Plexos license and FICO for providing its Xpress solver for mixed integer programming. We would like to thank the editor and anonymous referees for helpful comments. 


\section{References}

1. Akmal M., Fox B., Morrow D. J. and Littler T., "Impact of High Penetration of Heat Pumps on Low Voltage Distribution Networks," in PowerTech, Trondheim, 2011.

2. Alva G., Lin Y., Fang G. 2018. "An overview of thermal energy storage systems." Energy 144: 341-378.

3. Baringa, "Electricity System Analysis - future system benefits from selected DSR scenarios," August 2012. [Online]. Available: https://www.gov.uk/government/uploads/system/uploads/attachment_data/fi le/48551/5759-electricity-system-analysis--future-system-benefit.pdf. [Accessed January 2017].

4. Bianco V., Scarpa F., Tagliafico L. A., 2015 "Long term outlook of primary energy consumption of the Italian thermoelectric sector: Impact of fuel and carbon prices." Energy 2015; 87: 153-164.

5. Bianco V., Scarpa F., Tagliafico L. A, "Estimation of primary energy savings by using heat pumps for heating purposes in the residential sector." Applied Thermal Engineering 2017; 114: 938-47.

6. Gan CK, Mancarella P, Pudjianto D and Strbac G, "Statistical appraisal of economic design strategies of LV," Electric Power Systems Research, doi:10.1016/j.epsr.2011.02.001, 2011.

7. Commission for Energy Regulation, "CER National Smart Metering Programme. Smart Metering High Level Design," Dublin: Commission for Energy Regulation; 2014. Available: https://www.cru.ie/wp-content/uploads/2014/07/CER14046High-Level-Design.pdf. [cccessed 30 January 2018].

8. Chiodi A., Gargiulo M., Deane J.P., Lavigne D.,.Rout U. K, ÓGallachóir B. P, "Modelling the impacts of challenging 2020 non-ETS GHG emissions reduction targets on Ireland's energy system," Energy Policy, 2013, 62:1438-145

9. Committee on Climate Change, "Fourth Carbon Budget Review - part 2. The costeffective path to the 2050 target," London, Committee on Climate Change; 2013. Available: https://www.theccc.org.uk/wp-content/uploads/2013/12/1785aCCC_AdviceRep_Singles_1.pdf. [accessed 30 January 2018].

10. Committee on Climate Change, "The Fourth Carbon Budget. Reducing emissions through the 2020s," London: Committee on Climate Change; 2010. Available: https://www.theccc.org.uk/archive/aws2/4th\%20Budget/CCC_4thBudget_interactive.pdf. [accessed 30 January 2018].

11. Deane JP, Chiodi A, Gargiulo M, OCallachoir BP, "Soft-linking of a power systems model to an energy systems model," Energy, 42; 2012: 303-12

12. Denny E., Tuohy A., Meibom P., Keane A., Flynn D., Mullane A., O’Malley M.. The impact of increased interconnection on electricity systems with large penetrations of wind generation: A case study of Ireland and Great Britain. Energy Policy, 2010; 38: 6946-54.

13. Department of Communications, Energy and Natural Resources, "National Renewable Energy Action Plan. Ireland," Dublin: Department of 
Communications, Energy and Natural Resources; 2009.

https://www.dccae.gov.ie/documents/The\%20National\%20Renewable\%20Ene rgy\%20Action\%20Plan\%20(PDF).pdf [accessed 30 January 2018].

14. Department of Energy and Climate Change, "DECC Fossil fuel price projections," London: Department of Energy and Climate Change; 2013.

https://www.gov.uk/government/uploads/system/uploads/attachment_data/fi le/212521/130718 decc-fossil-fuel-price-projections.pdf [accessed 30 January 2018].

15. Department of Energy and Climate Change, "Electricity Generation Costs

(December 2013)," London: Department of Energy and Climate Change; 2013. https://www.gov.uk/government/uploads/system/uploads/attachment_data/fi le/269888/131217_Electricity_Generation_costs_report_December_2013_Final.p df. [accessed 30 January 2018].

16. Department of Enterprise, Trade and Investment, "Consultation on the potential for extending the natural gas network in Northern Ireland," Belfast: Department of Enterprise, Trade and Investment; 2011. https://www.economyni.gov.uk/sites/default/files/consultations/deti/extending-natural-gasnetwork-ni.pdf. [Accessed 30 January 2018].

17. Department of Enterprise, Trade and Investment, "Northern Ireland Strategic Energy Framework," Belfast: Department of Enterprise, Trade and Investment; 2010 https://www.economy-

ni.gov.uk/sites/default/files/publications/deti/sef\%202010.pdf. [Accessed 30 January 2018]

18. Dimplex, "The Heatbook," March 2015. [Online]. Available: https://www.dimplex.co.uk/sites/default/files/Heat\%20Book\%2015.pdf. [Accessed 30 January 2018].

19. EirGrid, SONI, "All-Island generation capacity statement 2015 - 2024," 2015. http://www.soni.ltd.uk/media/documents/Operations/CapacityStatements/All \%20Island\%20Generation\%20Capacity\%20Statement\%202015\%20$\% 202024 . p d f$. [accessed 30 January 2018].

20. EirGrid "Quick Guide to the Integrated Single Electricity Market", 2016. http://www.eirgridgroup.com/ uuid/f110639e-9e21-4d28-b193ed56ee372362/EirGrid-Group-I-SEM-Quick-Guide.pdf [accessed 30 January 2018]

21. EirGrid, 2017. Celtic interconnection. Project Upate 2017. [Online] Available at: http://www.eirgridgroup.com/site-files/library/EirGrid/CelticInterconnector-Project-Update-Brochure.pdf [Accessed 30 January 2018]

22. EirGrid, SONI, "All-Island generation capacity statement 2017 - 2026," 2017. http://www.eirgridgroup.com/sitefiles/library/EirGrid/4289_EirGrid_GenCapStatement_v9_web.pdf. [accessed 30 January 2018].

23. Element Energy, Frontier Economics."Economic analysis for the Renewable Heat Incentive for Ireland." Cambridge: Element Energy Limited: 2017. Accessed January 15, 2018.

https://www.dccae.gov.ie/documents/Economic\%20analysis $\% 20$ for $\% 20$ the $\% 2$ 0RHI\%20in\%20Ireland.pdf.

24. Energy Saving Trust, "Detailed analysis from the second phase of the Energy Saving Trust's heat pump field trial," May 2013. [Online]. Available: 
https://www.gov.uk/government/uploads/system/uploads/attachment_data/fi le/225825/analysis_data_second_phase_est_heat_pump_field_trials.pdf. [Accessed 30 January 2018].

25. EU COMMISSION, "An EU Strategy on Heating and Cooling," Brussels: Commission of the European Communities; 2016. https://ec.europa.eu/energy/sites/ener/files/documents/1_EN_ACT_part1_v14. pdf. [accessed 30 January 2018].

26. Fischer D., Madani H., 2017. "On heat pumps in smart grids: A review." Renewable and Sustainable Energy Reviews 70: 342-57.

27. Frontier Economics, ElementEnergy, "Pathways to high penetration of heat pumps. Report prepared for the Committee on Climate Change," London: Frontier Economics; 2013. https://www.theccc.org.uk/wpcontent/uploads/2013/12/Frontier-Economics-Element-Energy-Pathways-tohigh-penetration-of-heat-pumps.pdf [accessed 30 January 2018].

28. Gaffney F., J.P. Deane, ÓGallachóir B.P., A 100 year review of electricity policy in Ireland (1916-2015). Energy Policy, 2017; 105: 67-79.

29. Glatzmaier G., "Developing a Cost Model and Methodology to Estimate Capital Costs for Thermal Energy Storage," Technical Report NREL/TP-5500-53066, 2011. https://www.nrel.gov/docs/fy12osti/53066.pdf [accessed 30 January 2018]

30. IEA, IRENA, ETSAP, "Thermal Energy Storage Technology Brief," January 2013. https://www.irena.org/DocumentDownloads/Publications/IRENAETSAP\%20Tech\%20Brief\%20E17\%20Thermal\%20Energy\%20Storage.pdf [accessed 30 January 2018].

31. IPSOS MORI, "Consumer Experiences Of Time of Use Tariffs," 2012. https://www.ipsos.com/sites/default/files/publication/1970-01/Ipsos-MORIreport-on-Consumer-Experiences-Of-Time-Of-Use-Tariffs.pdf [Accessed 30 January 2018].

32. Green J.P., Smith S.A., and Strbac G., "Evaluation of electricity distribution system design strategies," Generation, Transmission and Distribution, IEEE Proceedings, 1999; 146: 53 - 60.

33. Keatley P., Shibli A., Hewitt N.J., "Estimating power plant start costs in cyclic operation," Applied Energy, 2013; 111: 550-7.

34. Kelly NJ, Cockroft J., "Analysis of retrofit air source heat pump performance : results from detailed simulations and comparison to field trial data," Energy and Buildings, 2011; 43: 239-45

35. Luo X., Wang J., Dooner M., Clarke J., "Overview of current development in electrical energy storage technologies and the application potential in power system operation," Applied Energy, 2015: 137 5011-536.

36. Mancarella P., C. K. Gan, Strbac G., "Evaluation of the impact of electric heat pumps and distributed CHP on LV networks," in IEEE PowerTech, Trondheim, 2011.

37. National Grid, "UK Future Energy Scenarios, July 2014" Warwick: National Grid plc; 2014. http://fes.nationalgrid.com/media/1298/2014-fes.pdf. [accessed 30 January 2018].

38. Nsanzineza R., O’Connell M., Brinkman G., Milford J. B., "Emissions implications of downscaled electricity generation scenarios for the western United States," Energy Policy;109: 601-608 
39. Northern Ireland Electricity, "SHIFT\&SAFE. Making Coleraine’s Netwroks Smart," 2014. [Online]. Available: http://www.nie.co.uk/documents/Shift-Saveleaflet.aspx. [accessed 30 January 2018].

40. Northern Ireland Statistics and Research Agency, "Northern Ireland Census 2011, General Report" Belfast: Northern Ireland Statistics and Research Agency; 2015. https://www.nisra.gov.uk/sites/nisra.gov.uk/files/publications/2011census-general-report.pdf [accessed 30 January 2018].

41. Richardson, P. "Integration of Distributed Energy Resources in Low Voltage Electricity Networks." PhD thesis, College of Engineering and Architecture, UCD, 2012.

42. Sustainable Energy Authority of Ireland, "Residental Energy Roadmap," Dublin: Sustainable Energy Authority of Ireland; 2011.

https://www.seai.ie/resources/publications/Residential-Energy-Roadmap.pdf. [accessed 30 January 2018].

43. Sustainable Energy Authority of Ireland, "SmartGrid Roadmap," Dublin: Sustainable Energy Authority of Ireland; 2011. https://www.seai.ie/resources/publications/Smartgrid-Roadmap.pdf [accessed 30 January 2018]

44. Single Electricity Market Committee, "DS3 System Services Procurement Design and Emerging Thinking. Decision paper," 19 December 2014. https://www.semcommittee.com/sites/semcommittee.com/files/mediafiles/SEM-14-108\%20DS3\%20System\%20Services\%20Decision\%20Paper.pdf [accessed 30 January 2018].

45. Single Electricity Market Committee, "Integrated Single Electricity Market (ISEM): SEM Committee Decision on High Level Design. Impact Assessment", 17 September 2014

https://www.semcommittee.com/sites/semcommittee.com/files/mediafiles/SEM-14-085b\%20ISEM\%20SEMC\%20decision\%20on\%20HLD\%20Impact\%20Assessment.pdf [accessed 30 January 2018].

46. Strbac, G. C. Kim Gan, M. Aunedi, V. Stanojevic, P. Djapic, J. Dejvises et al. "Benefits of Advanced Smart Metering for Demand Response based Control of Distribution Networks," 2010.

http://www.energynetworks.org/assets/files/electricity/futures/smart_meters /Smart_Metering_Benerfits_Summary_ENASEDGImperial_100409.pdf [accessed 30 January 2018].

47. Strbac G., Aunedi M., Pudjianto D., Djapic P., Teng F., Sturt A et al. "Strategic Assessment of the Role and Value of Energy Storage Systems in the UK Low Carbon Energy Future, Report for the Carbon Trust" London: Imperial College London; 2012. https://www.carbontrust.com/media/129310/energy-storagesystems-role-value-strategic-assessment.pdf [accessed 30 January 2018]

48. Vorushylo I., Keatley P., Hewitt N. J., "Most promising flexible generators for the wind dominated market," Energy Policy, 96; 2016: 564-75.

49. Zhang H., Baeyens J., Cáceres G., Degrève J., Lv Y.. 2016. "Thermal energy storage: Recent developments and practical aspects." Progress in Energy and Combustion Science 53: 1-40.

50. Zhao H, Wu Q, Hu S, Xu H, Rasmussen CN, "Review of energy storage system for wind power integration support," Applied Energy, 2015; 137: 545-54. 


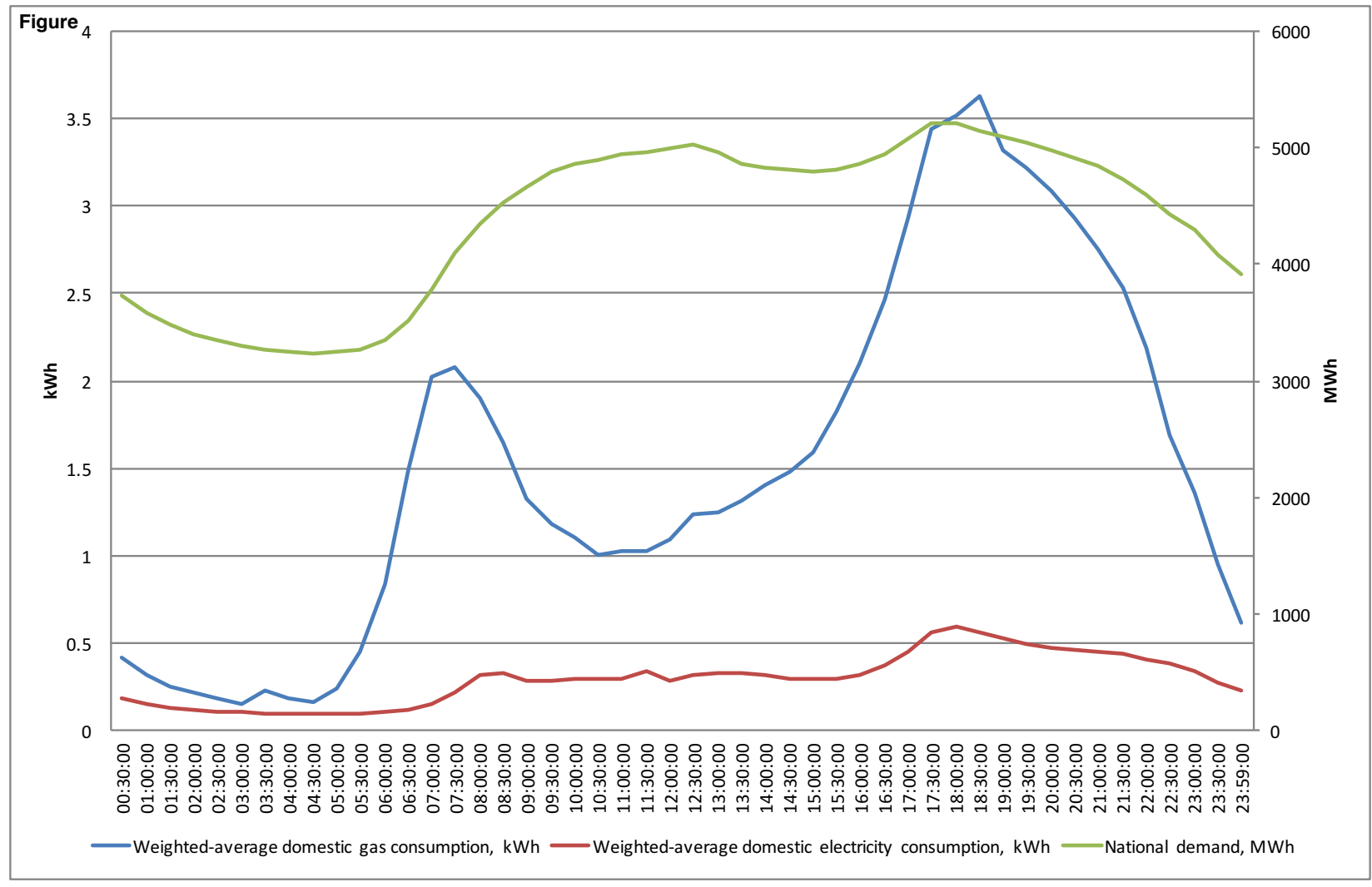




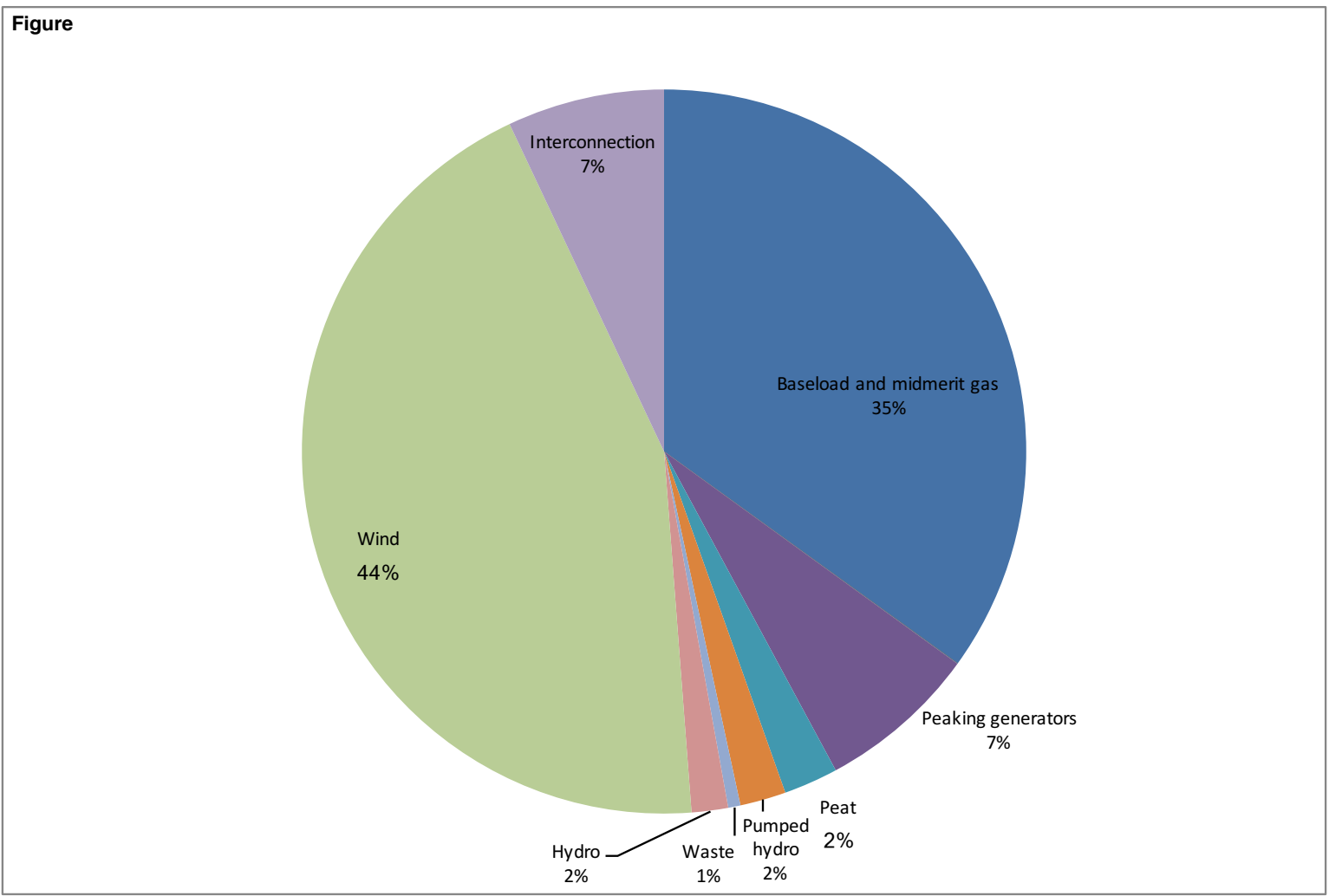




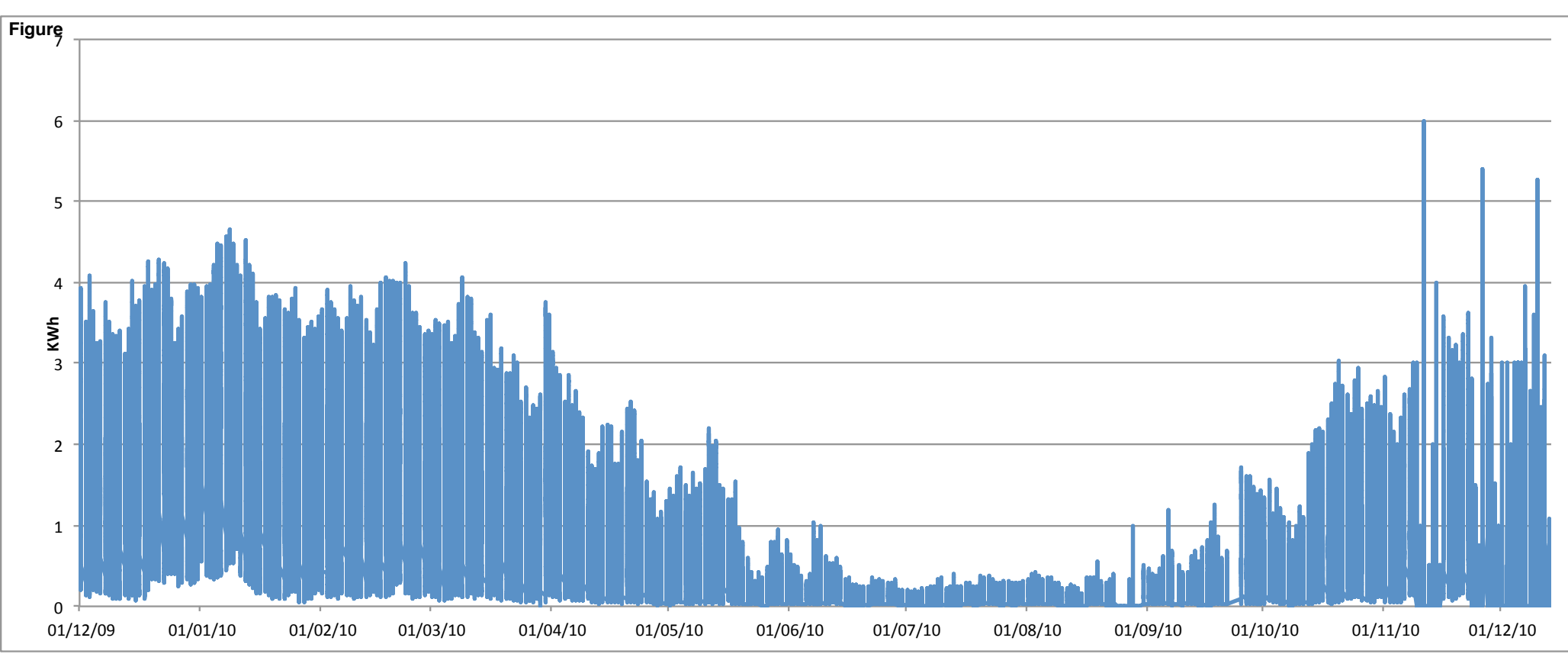


Figure

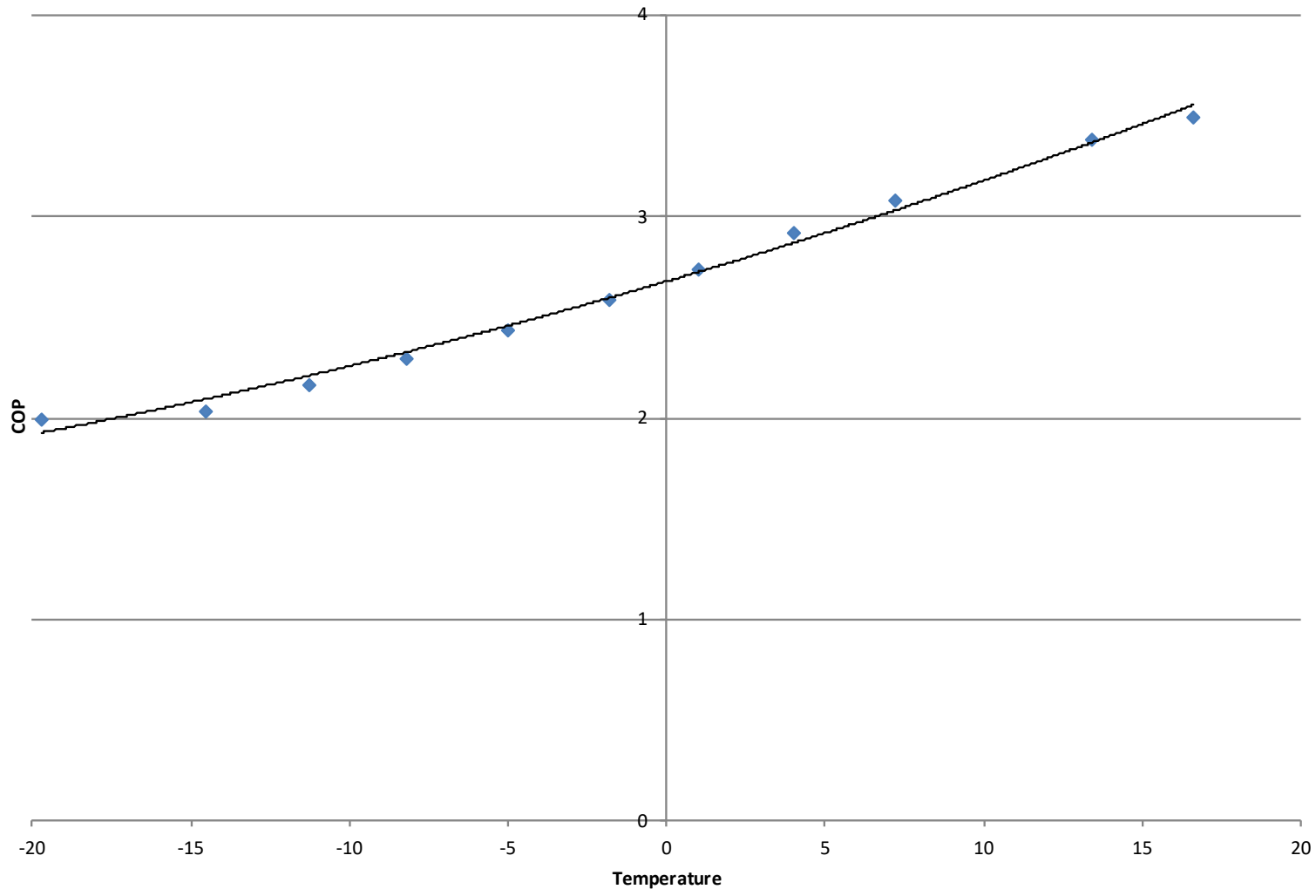




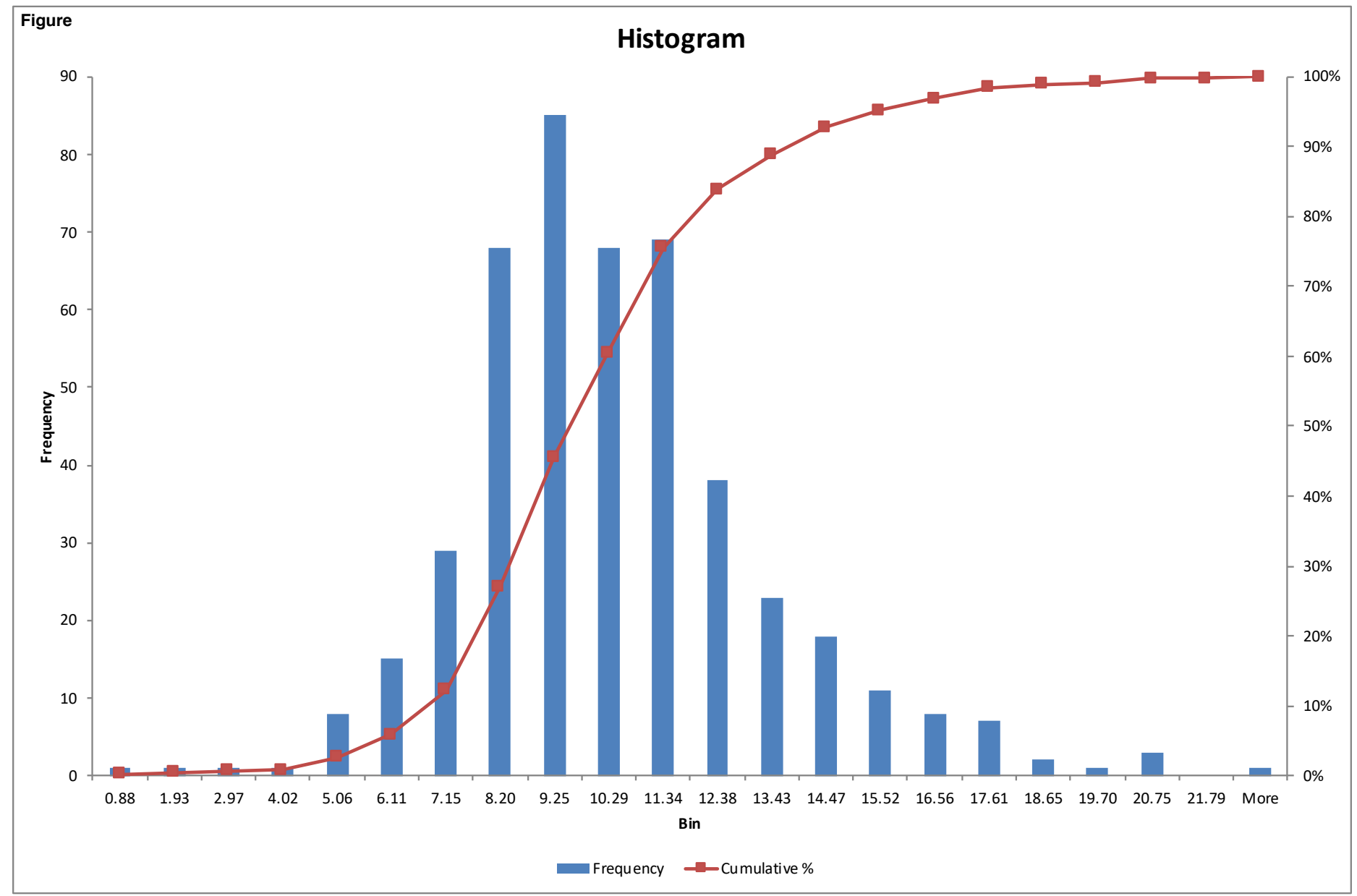





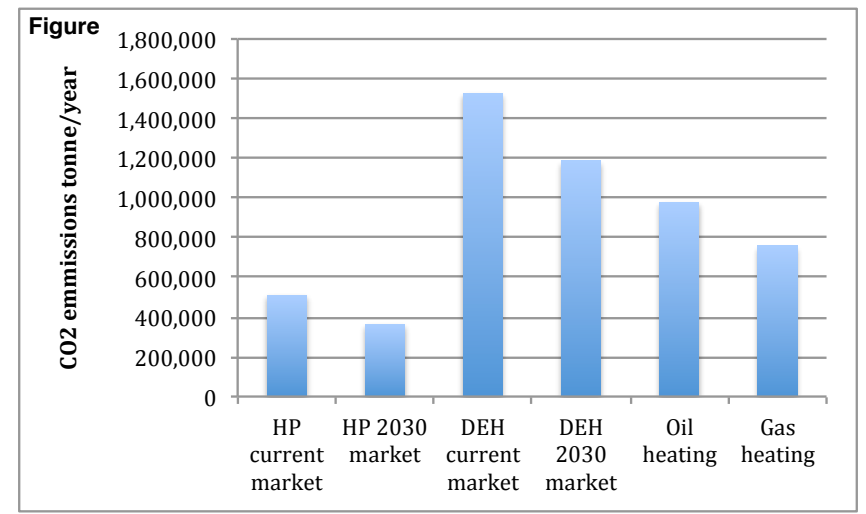


Table 3.1 - Scenarios overview

\begin{tabular}{|c|c|}
\hline Scenario name & Description \\
\hline $\mathrm{HP}$ & Heat pump electrification, $20 \%$ of domestic heating sector \\
\hline $\mathrm{HP}+1 \mathrm{~h} \mathrm{ES}$ & $\begin{array}{l}\text { Heat pump electrification with domestic thermal storage tank } \\
\text { supplying energy for } 1 \mathrm{~h}^{*}\end{array}$ \\
\hline $\mathrm{HP}+2 \mathrm{~h} \mathrm{ES}$ & $\begin{array}{l}\text { Heat pump electrification with domestic thermal storage tank } \\
\text { supplying energy for } 2 \mathrm{~h}^{*}\end{array}$ \\
\hline $\mathrm{HP}+3 \mathrm{~h} \mathrm{ES}$ & $\begin{array}{l}\text { Heat pump electrification with domestic thermal storage tank } \\
\text { supplying energy for } 3 \mathrm{~h}^{*}\end{array}$ \\
\hline $\mathrm{HP}+4 \mathrm{~h} \mathrm{ES}$ & $\begin{array}{l}\text { Heat pump electrification with domestic thermal storage tank } \\
\text { supplying energy for } 4 \mathrm{~h}^{*}\end{array}$ \\
\hline $\mathrm{DEH}$ & Direct electric heating, $20 \%$ of domestic heating sector \\
\hline $\mathrm{DEH}+1 \mathrm{~h} \mathrm{ES}$ & $\begin{array}{l}\text { DEH with domestic thermal storage tank supplying energy for } 1 \\
\mathrm{~h}^{*}\end{array}$ \\
\hline $\mathrm{DEH}+2 \mathrm{~h} \mathrm{ES}$ & $\begin{array}{l}\text { DEH with domestic thermal storage tank supplying energy for } 2 \\
h^{*}\end{array}$ \\
\hline $\mathrm{DEH}+3 \mathrm{~h} \mathrm{ES}$ & $\begin{array}{l}\text { DEH with domestic thermal storage tank supplying energy for } 3 \\
h^{*}\end{array}$ \\
\hline $\mathrm{DEH}+4 \mathrm{~h} \mathrm{ES}$ & $\begin{array}{l}\text { DEH with domestic thermal storage tank supplying energy for } 4 \\
h^{*}\end{array}$ \\
\hline
\end{tabular}

*Volume of storage tank is based on maximum winter peak demand per average household (detailed methodology is described in methodology section)

Table 4.1 - Fuel and carbon emissions prices implemented in the SEM 2030 model (DECC 2013)

\begin{tabular}{|c|c|}
\hline Fuel & Price \\
\hline Gas, $€ / G J$ & 3.68 \\
\hline Coal, $€ / G J$ & 9.15 \\
\hline Distillate, $€ / G J$ & 27.9 \\
\hline Oil, $€ / G J$ & 18.4 \\
\hline Carbon, $€ /$ tonne & 37 \\
\hline
\end{tabular}

Table 4.2 - Electricity demand assumptions for 2030 SEM model (EirGrid, SONI, 2017) (SEM Committee, 2014)

\begin{tabular}{|l|l|l|}
\hline Time horizon & Total demand, TWh & Transmission peak, GW \\
\hline 2015 & 36.7 & 6.6 \\
\hline 2030 & 43.2 & 7.8 \\
\hline
\end{tabular}


Table 4.3 - Total electricity demand increase due to the installation of HP and DEH

\begin{tabular}{|l|l|}
\hline Type of heating & Additional yearly demand, GWh \\
\hline DEH & 3,718 \\
\hline HP & 1,478 \\
\hline
\end{tabular}

Table 4.4 - Descriptive statistics of peaks in domestic heating demand

\begin{tabular}{|lr|}
\hline Mean & 9.96 \\
\hline Standard Error & 0.13 \\
\hline Median & 9.65 \\
\hline Mode & 10 \\
\hline Standard Deviation & 2.88 \\
\hline Sample Variance & 8.28 \\
\hline
\end{tabular}

Table 4.5 - Energy storage parameters for DSM scenarios

\begin{tabular}{|c|c|c|}
\hline Scenario & Storage volume, GWh & Storage capacity, GW \\
\hline HP/DEH + 1h ES & 5.85 & 5.85 \\
\hline HP/DEH + 2h ES & 11.70 & 5.85 \\
\hline HP/DEH+ 3h ES & 17.55 & 5.85 \\
\hline HP/DEH + 4h ES & 23.39 & 5.85 \\
\hline
\end{tabular}

Table 5.1 - Comparison of $\mathrm{CO} 2$ emissions due to heat electrification in different scenarios

\begin{tabular}{|c|c|c|c|c|c|c|c|c|c|c|c|}
\hline & BaU & HP & $\begin{array}{c}\text { HP }+ \\
\text { 1h ES }\end{array}$ & $\begin{array}{c}\text { HP }+ \\
\text { 2h ES }\end{array}$ & $\begin{array}{c}\text { HP }+ \\
\text { 3h ES }\end{array}$ & $\begin{array}{c}\text { HP }+ \\
\text { 4h ES }\end{array}$ & DEH & $\begin{array}{c}\text { DEH } \\
+1 h \\
\text { ES }\end{array}$ & $\begin{array}{c}\text { DEH } \\
+2 h \\
\text { ES }\end{array}$ & $\begin{array}{c}\text { DEH } \\
+3 h \\
\text { ES }\end{array}$ & $\begin{array}{c}\text { DEH } \\
+4 h \\
\text { ES }\end{array}$ \\
\hline $\begin{array}{c}\text { C02 emissions, } \\
\text { k tonne }\end{array}$ & 7,162 & 7,525 & 7,362 & 7,379 & 7,373 & 7,370 & 8,349 & 8,149 & 8,144 & 8,144 & 8,148 \\
\hline $\begin{array}{c}\text { CO2 } \\
\text { contributions, } \\
\%\end{array}$ & & 5.07 & 2.80 & 3.03 & 2.96 & 2.91 & 16.58 & 13.78 & 13.72 & 13.72 & 13.77 \\
\hline
\end{tabular}

Table 5.2 - Wind curtailments with the $75 \%$ SNSP

\begin{tabular}{|l|l|l|l|l|l|l|l|l|l|l|l|}
\hline & BaU & HP & $\begin{array}{l}\text { HP + } \\
1 \mathrm{~h} \mathrm{ES}\end{array}$ & $\begin{array}{l}\text { HP } \\
2 \mathrm{~h} \mathrm{ES}\end{array}$ & $\begin{array}{l}\mathrm{HP}+ \\
3 \mathrm{~h} \mathrm{ES}\end{array}$ & $\begin{array}{l}\mathrm{HP}+{ }^{+} \\
4 \mathrm{~h} \mathrm{ES}\end{array}$ & DEH & $\begin{array}{l}\text { DEH } \\
+1 \mathrm{~h}\end{array}$ & $\begin{array}{l}\text { DEH } \\
+2 \mathrm{~h}\end{array}$ & $\begin{array}{l}\text { DEH } \\
+3 \mathrm{~h}\end{array}$ & $\begin{array}{l}\text { DEH } \\
+4 \mathrm{~h}\end{array}$ \\
\hline
\end{tabular}




\begin{tabular}{|l|l|l|l|l|l|l|l|l|l|l|l|}
\hline & & & & & & & & ES & ES & ES & ES \\
\hline $\begin{array}{l}\text { Wind curtailment, } \\
\%\end{array}$ & -7.20 & -6.43 & -4.81 & -4.81 & -4.80 & -4.82 & -5.43 & -2.94 & -2.93 & -2.93 & -2.94 \\
\hline
\end{tabular}

Table 5.3 - Impact of heat electrification on baseload generation

\begin{tabular}{|l|l|l|l|l|l|l|l|l|l|l|l|}
\hline $\begin{array}{l}\text { Number of } \\
\text { start-ups }\end{array}$ & BaU & HP & $\begin{array}{l}\text { HP + } \\
\text { 1h ES }\end{array}$ & $\begin{array}{l}\text { HP }+ \\
\text { 2h ES }\end{array}$ & $\begin{array}{l}\text { HP }+ \\
3 h \text { ES }\end{array}$ & $\begin{array}{l}\text { HP + } \\
4 h \text { ES }\end{array}$ & DEH & $\begin{array}{l}\text { DEH } \\
+1 h \\
\text { ES }\end{array}$ & $\begin{array}{l}\text { DEH } \\
+2 h \\
\text { ES }\end{array}$ & $\begin{array}{l}\text { DEH } \\
+3 h \\
\text { ES }\end{array}$ & $\begin{array}{l}\text { DEH } \\
+4 h \\
\text { ES }\end{array}$ \\
\hline $\begin{array}{l}\text { Baseload } \\
\text { start-ups }\end{array}$ & 396 & 459 & 360 & 358 & 344 & 346 & 553 & 390 & 384 & 402 & 394 \\
\hline $\begin{array}{l}\text { Difference, } \\
\%\end{array}$ & & 15.91 & -9.09 & -9.60 & -12.63 & -13.13 & 39.65 & -1.52 & -3.03 & 1.52 & -0.51 \\
\hline
\end{tabular}

Table 6.1 - Major economic results of heat electrification in the SEM

\begin{tabular}{|c|c|c|c|c|c|c|c|c|c|c|c|}
\hline Parameter & $\mathrm{BaU}$ & HP & $\begin{array}{l}\mathrm{HP}+ \\
1 \mathrm{~h} \mathrm{ES}\end{array}$ & $\begin{array}{l}\mathrm{HP}+ \\
2 \mathrm{~h} \mathrm{ES}\end{array}$ & $\begin{array}{l}\mathrm{HP}+ \\
3 \mathrm{~h} \mathrm{ES}\end{array}$ & $\begin{array}{l}\mathrm{HP} \quad+ \\
4 \mathrm{~h} \mathrm{ES}^{-}\end{array}$ & DEH & $\begin{array}{l}\text { DEH } \\
+1 \mathrm{~h} \mathrm{ES}\end{array}$ & $\begin{array}{l}\text { DEH } \\
+2 \mathrm{~h} \mathrm{ES}\end{array}$ & $\begin{array}{l}\text { DEH } \\
+3 \mathrm{~h} \mathrm{ES}\end{array}$ & $\begin{array}{l}\text { DEH } \\
+4 \mathrm{~h} \\
\mathrm{ES}\end{array}$ \\
\hline $\begin{array}{l}\text { Total } \\
\text { system } \\
\text { costs, €, m }\end{array}$ & 3,289 & 3,650 & 3,600 & 3,516 & 3,479 & 3,462 & 5,002 & 4,035 & 4,062 & 4,134 & 3,993 \\
\hline $\begin{array}{l}\text { Difference, } \\
€, m\end{array}$ & & 361 & 312 & 228 & 190 & 173 & 1,713 & 747 & 773 & 845 & 704 \\
\hline $\begin{array}{l}\text { Difference, } \\
\%\end{array}$ & & 10.97 & 9.47 & 6.92 & 5.78 & 5.73 & 52.07 & 22.70 & 23.51 & 25.70 & 21.40 \\
\hline $\begin{array}{l}\text { Dispatch } \\
\text { costs with } \\
75 \% \text { SNSP, } \\
€, \mathrm{~m}\end{array}$ & 3,543 & 3,728 & 3,724 & 3,696 & 3,695 & 3,619 & 5,177 & 3,809 & 3,742 & 3,756 & 3,748 \\
\hline $\begin{array}{l}\text { Dispatch } \\
\text { costs with } \\
75 \% \text { SNSP, } \\
\%\end{array}$ & & 5.22 & 5.12 & 4.33 & 4.30 & 2.15 & 46.13 & 7.52 & 5.63 & 6.01 & 5.78 \\
\hline $\begin{array}{l}\text { ES } \\
\text { profitability, } \\
€, m\end{array}$ & & & 14.15 & 17.83 & 15.85 & 14.81 & & 52.13 & 49.61 & 48.74 & 46.78 \\
\hline
\end{tabular}


Table 6.2 - Comparison between costs associated with the network extension and HP installation

\begin{tabular}{|l|l|l|l|}
\hline & & Household/yearly, $€$ & $\begin{array}{l}\text { Market, } €, \text { m }(20 \% \text { of } \\
\text { households) }\end{array}$ \\
\hline Gas & Network extension & $726-1,866$ & $409-1,052$ \\
\hline & Boiler installation & $212-424$ & $120-239$ \\
\hline & Total & $938-2290$ & $529-1,291$ \\
\hline HP & Capex (installation) & $764-1273$ & $431-718$ \\
\hline & Electricity market costs & $135-328$ & $76-185$ \\
\hline & Total & $899-1,601$ & $507-903$ \\
\hline
\end{tabular}

